Keigwin, L.D., Rio, D., Acton, G.D., and Arnold, E. (Eds.)

Proceedings of the Ocean Drilling Program, Scientific Results Volume 172

\section{IRON OXIDATION IN SEDIMENT CORES (SITE 1062) DURING SIX MONTHS Of Storage in the OCEAN DRILLING Program ARChIVE ${ }^{1}$}

\author{
I. König, ${ }^{2}$ A. Lougear, ${ }^{3}$ P. Bruns, ${ }^{4}$ J. Grützner, ${ }^{2}$ A.X. Trautwein, ${ }^{3}$ \\ and W.-C. Dullo ${ }^{2}$
}

${ }^{1}$ König, I., Lougear, A., Bruns, P., Grützner, J., Trautwein, A.X., and Dullo, W.-C., 2000. Iron oxidation in sediment cores (Site 1062) during six months of storage in the Ocean Drilling Program archive. In Keigwin, L.D., Rio, D., Acton, G.D, and Arnold, E. (Eds.), Proc. ODP, Sci. Results, 172, 111 [Online]. Available from World Wide Web: <http://wwwodp.tamu.edu/publications/172_SR/ VOLUME/CHAPTERS/SR172_02.PDF>. [Cited YYYY-MM-DD]

${ }^{2}$ GEOMAR Research Center for Marine Geosciences, Wischhofstrasse 1-3, 24148 Kiel, Federal Republic of Germany. Correspondence author: ikoenig@geomar.de

${ }^{3}$ Institute of Physics, Medical University of Lübeck, Ratzeburger Allee 160, 23538 Lübeck, Federal Republic of Germany.

${ }^{4}$ Faculteit der Aardwetenschappen, De Boelelaan 1085, 1081 HV Amsterdam, The Netherlands.

Initial receipt: 24 August 1999 Acceptance: 6 March 2000 Web publication: 1 September 2000 Ms 172SR-214 


\section{KöNIG ET AL. \\ Iron Oxidation In Sediment Cores (Site 1062)}

Fe(II) redox transition has taken place in the seabed. Therefore, the reversible shift, if it were measured under controlled reoxidation in the laboratory, may suggest the chemical stress that was suffered by the iron oxide minerals at the ocean bottom. Concerning Site 1062, this process might help to judge both the authenticity of magnetic field excursion records and the lithostratigraphic value of red lutites at given sediment depths.

Although the nature and extent of information loss or alteration during storage depend on sediment type, the reported observations emphasize the need for special sample protection with respect to properties that might be affected.

\section{INTRODUCTION}

The Deep Sea Drilling Project (DSDP) and Ocean Drilling Program (ODP) sediment archives contain a comprehensive record of Earth's history and paleoceanography. Within a few years of core retrieval, most shore-based examinations have been accomplished such that each section of the cores has been assessed with respect to stratigraphy, time scales, proxy data, and correlations among cores. Thus, high-precision subsampling for particular scientific tasks may be performed, which makes the archive cores especially precious. However, some physical or chemical properties of the sediment cores might change during storage in the repository.

In particular, Fe-bearing minerals have been found to react very sensitively to variations of the redox environment. Diverse early diagenetic processes have been documented in this context-for example, reversible sediment color changes related to redox transitions of the structural iron in the clay mineral content of the sediments (Lyle, 1983), as well as alterations of the primary sediment magnetic signal due to authigenic magnetite $\left(\mathrm{Fe}_{3} \mathrm{O}_{4}\right)$ formation (Karlin et al., 1987). More recent studies have revealed that redox transitions of the structural clay iron in sediments imply formation or destruction, respectively, of potent geochemical structures (König et al., 1999), which also represent a new type of proxy for the paleoredox conditions at the ocean floor.

Earlier studies have demonstrated drastic differences in the bulk sediment $\mathrm{Fe}(\mathrm{II}) / \mathrm{Fe}(\mathrm{III})$ ratio as a result of differences in sample handling prior to analysis: air drying of anoxic sediments has resulted in $\mathrm{Fe}(\mathrm{II})$ to $\mathrm{Fe}(\mathrm{III})$ oxidation of a substantial fraction of the $\mathrm{Fe}(\mathrm{II})$ content (e.g., $>20 \%$ of the total Fe, or $\sim 40 \%$ of the initial Fe(II) content [König et al., 1988]). Thus, careful protection of anoxic sediment samples from contact with atmospheric oxygen is imperative with respect to the investigation of parameters that may be modified by Fe redox transitions. In this study, we examine the extent and nature of geochemical alterations that occur in the Fe-bearing mineral content of deep-sea sediments during 6 months of storage in the ODP Bremen Core Repository.

\section{MATERIALS AND METHODS}

The investigation was conducted using materials collected during ODP Leg 172, which recovered a sequence of sediment cores along a depth transect in the westernmost North Atlantic to obtain a detailed history of late Neogene climate change. Eleven sites were cored on the Carolina Slope, along the Blake-Bahama Outer Ridge, on the Bermuda 
Rise, and on the Sohm Abyssal Plain. Hole $1062 \mathrm{~A}\left(30^{\circ} 45.6^{\prime} \mathrm{N}\right.$, $74^{\circ} 28.0^{\prime} \mathrm{W}$ ) was retrieved at a water depth of $4763 \mathrm{~m}$ on the eastern flank of a mud wave, located in a mud wave field in the Bahama Basin (Shipboard Scientific Party, 1998a).

For our study, 12 samples (three samples per core from Cores 172$1062 \mathrm{~A}-10 \mathrm{H}$ through $13 \mathrm{H}$ ) were taken during the cruise shortly after opening the cores. The samples cover the depth range from 80 to 114 meters below seafloor (mbsf), which-according to an astronomic time scale for Site 1062 (J. Grützner et al., unpubl. data)-is equivalent to an age interval of 655 to 1066 k.y. (Table T1). During sampling, preference was given to clay-rich sediments to avoid strong "dilution" of the sediment iron by biogenic hard parts. Moreover, care was taken that different sediment colors, ranging from reddish brown to dark olive green, were represented. Immediately after sampling $\left(10 \mathrm{~cm}^{3}\right.$ per sample), the sediment was double bagged in plastic and stored in a liquid nitrogen container that allowed shipping of the samples to our laboratory at temperatures below $-40^{\circ} \mathrm{C}$.

After 6 months of storage in the Bremen repository, cores were resampled at the same depth intervals. In order to avoid any additional alteration caused by transport, samples were packed in plastic bags and immediately cooled in liquid nitrogen. They remained in liquid nitrogen during transport and until measurement. The samples were investigated with respect to the distributions of the sediment iron among its two valence states $\mathrm{Fe}(\mathrm{II})$ and $\mathrm{Fe}(\mathrm{III})$, as well as the different iron minerals present, using Mössbauer spectroscopy. This element-specific method sensitively measures the hyperfine interactions between the iron nuclei and their electronic environment (Gütlich et al., 1978). Mössbauer spectra of bulk sediment samples are composite spectra, composed of subspectra that quantitatively represent the respective sedimentary iron species (Fig. F1). Whereas some of the subspectra are distinguishable, others overlap so much that they cannot be readily separated from each other. However, investigation of the samples at a variety of selected temperatures below room temperature, as well as the application of external magnetic fields during measurement, results in further distinction of individual subspectra.

A sequence of steps was followed systematically in order to achieve the maximum possible identification and quantification of different geochemical iron species. At room temperature, the respective fractions of $\mathrm{Fe}(\mathrm{II})$ in (1) silicate minerals, (2) siderite $\left(\mathrm{FeCO}_{3}\right)$, and (3) vivianite $\left[\mathrm{Fe}_{3}\left(\mathrm{PO}_{4}\right)_{2} \cdot 8 \mathrm{H}_{2} \mathrm{O}\right]$, as well as (4) the overall sum of $\mathrm{Fe}(\mathrm{III})$ plus low-spin (sulfidic) Fe(II), can be determined (König and Hollatz, 1990). This differentiation is also possible at $77 \mathrm{~K}\left(-196^{\circ} \mathrm{C}\right)$, which helps prevent sample oxidation during measurement and was therefore the preferred temperature in the present study (Fig. F1A). To obtain further differentiation between individual chemical iron species in the sediment samples - that is, to discriminate between high-spin Fe(III) in silicate minerals, oxides, and oxyhydroxides as well as low-spin $\mathrm{Fe}(\mathrm{II})$ in sulfides-selected samples were also measured at 4.2 and $0.3 \mathrm{~K}$ (Fig. F1B), with and without external magnetic fields of $7 \mathrm{~T}$ (Tesla) and $1 \mathrm{~T}$, respectively (A. Lougear et al., unpubl. data).

The error margin of the total amount of $\mathrm{Fe}(\mathrm{II})$-without consideration of $\mathrm{Fe}(\mathrm{II})$ low-spin compounds such as pyrite-and correspondingly of $\mathrm{Fe}(\mathrm{III})$, consists of a statistical error $(\sim 0.5 \%)$ and a possible systematic error. The latter results from different Lamb-Mössbauer factors of $\mathrm{Fe}(\mathrm{II})$ and $\mathrm{Fe}(\mathrm{III})$ species. Recalibrating the Fe(II) amount using
T1. Analyzed samples from Hole 1062A, including depth and age information, p. 10.
F1. Mössbauer spectra and mathematical simulations of a Site 1062 sediment sample from $94 \mathrm{mbsf}$, p. 8.

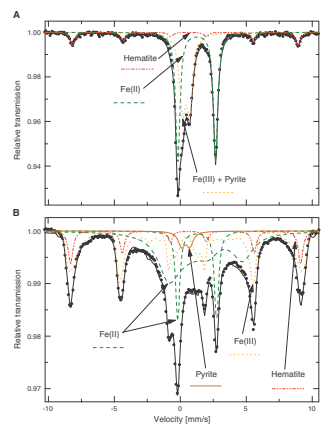


I. KöNIG ET AL.

the Debye model (Gütlich et al., 1978), with Debye temperatures $\Theta_{\mathrm{Fe}(\mathrm{II})}$ $\sim 350 \mathrm{~K}$ and $\Theta_{\mathrm{Fe}(\mathrm{III})} \sim 500 \mathrm{~K}$ (typical values for oxides, hydroxides, silicates, or carbonates; De Grave and Van Alboom, 1991), yields a systematic error of $1 \%$.

\section{RESULTS AND DISCUSSION}

All of the 12 sediment samples under examination experienced distinct redox changes within the 6 months between core retrieval and the sampling of the ODP archive core. Whereas the $\mathrm{Fe}(\mathrm{II}) / \mathrm{Fe}(\mathrm{III})$ ratio was near 50/50 in the initial material, between $12 \%$ and $24 \%$ of the total Fe in the sediment-that is, between $24 \%$ and $45 \%$ of the initial Fe(II)passed through a $\mathrm{Fe}(\mathrm{II})-\mathrm{Fe}(\mathrm{III})$ redox transition in that time period (Fig. F2). This result, obtained by Mössbauer spectroscopy at $77 \mathrm{~K}$, already documents the extent to which ODP sediment cores may undergo chemical alteration during storage. Moreover, a hematite $(\alpha$ $\mathrm{Fe}_{2} \mathrm{O}_{3}$ ) fraction could be clearly determined at $77 \mathrm{~K}$ (Fig. F1). This mineral is present in seven of the 12 samples; its contribution to the total Fe content varies between $6 \%$ and $11 \%$ and remains unchanged (within analytical precision) after 6 months of archive storage (Table T2). In the hematite-rich sediment layers, known as "red lutites," the hematite is of allochthonous nature, being derived from the Permian-Carboniferous deposits of the Canadian Maritime provinces (Shipboard Scientific Party, 1998c).

Both siderite and vivianite are below their Mössbauer detection limits in all of the 12 samples, although the method is very sensitive with respect to those two minerals (see König and Hollatz, 1990). This implies that $<1.5 \%$ of the bulk sediment iron can possibly be contained in siderite or vivianite. The ability to detect even minor siderite contents in sediments is of particular interest in the context of Leg 172 with respect to the gas hydrate that has been found in the Blake Ridge area (e.g., Paull, Matsumoto, Wallace, et al., 1996). Whereas one of the scientific objectives of Leg 172 was to assess the lateral distribution of gas hydrate and its related geochemical signatures within the continental rise (Shipboard Scientific Party, 1998b), close relations between these gas hydrate occurrences and carbonate diagenesis are a well-established fact (e.g., Lancelot and Ewing, 1972). Since siderite found in marine sediments is an indicator of carbonate authigenesis, this mineral might serve as a sensitive tracer.

Mössbauer spectroscopic examination of one of the samples (94 mbsf) at a large range of temperatures (300.0-0.3 K) revealed that the major part of the total Fe is structural Fe(II) or Fe(III) in the aluminosilica fraction (A. Lougear et al., unpubl. data). Whereas goethite ( $\alpha$ $\mathrm{FeOOH}$ ) was not detected, and its maximum possible contribution to the total iron, therefore, is $<1.5 \%$, small amounts $(\sim 3 \% \pm 1 \%$ of the total iron) of pyrite $\left(\mathrm{FeS}_{2}\right)$ could be identified (Fig. F1B).

The Fe(II) subspectrum depicted in Figure F1A can clearly be assigned to structural Fe(II) in silicate minerals. Separation of the Fe(II) subspectrum at $0.3 \mathrm{~K}$ (Fig. F1B) must result from different lattice Fe(II) neighborhoods. Hence, virtually the entire Fe(II) to Fe(III) oxidation process occurred within silicate mineral lattices. This implies significant modifications in both the sediment color (Lyle, 1983) and the geochemical redox reactivity (König et al., 1999), whereas the mineral contents remained unchanged.
F2. Fe(II) and Fe(III) fractions of the total iron content in 12 Site 1062 sediment samples, p. 9

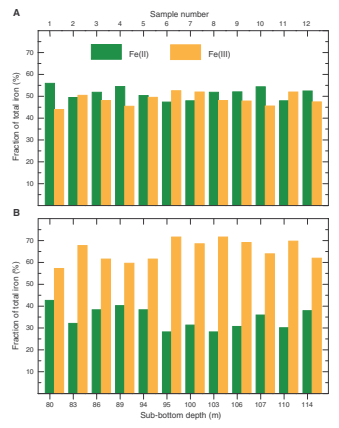

T2. Distribution of total iron among $\mathrm{Fe}(\mathrm{II}), \mathrm{Fe}(\mathrm{III})_{\text {total minus hematite, }}$ and $\mathrm{Fe}(\mathrm{III})_{\text {in hematite, }}$ p. 11. 


\section{KöNIG ET AL.

Markedly contrasting examples are known especially from freshwater systems, such as lake and river sediments that contain considerable amounts of siderite and vivianite (e.g., König and Hollatz, 1990). These two Fe(II) minerals are essentially transformed to Fe(III) oxides and oxyhydroxides upon contact with atmospheric oxygen (König et al., 1988). Even Blake Ridge-area sediments-other than the small series reported here-might contain important quantities of siderite originating from early diagenesis related to gas hydrates. On archive storage of the sediments, that portion may perhaps soon be transformed, as can be deduced from the pronounced oxidation processes observed in the present study.

Both findings, (1) small pyrite and negligible goethite contents in the presence of detrital hematite and (2) considerable amounts of the structural Fe(II) in the aluminosilica fraction that are oxidized to Fe(III) upon contact with atmospheric oxygen, imply that pronounced postdepositional diagenesis has occurred in the seafloor. Although the stage of iron reduction was obviously reached, there is only a minor indication of sulfidic conditions. Again, this may be different for Blake Ridge-area sediments outside of the series investigated and reported here.

Inasmuch as the deposition of the sediments happened in oxygenated bottom waters, the potential of the structural silicate Fe(II) to be oxidized to Fe(III) so easily (during storage) indicates that the inverse reaction (i.e., chemical Fe(III)-Fe(II) reduction) must have occurred to at least the same extent in the seafloor. Fe(III) oxides and oxyhydroxides would have been affected by the Fe(III)-Fe(II) reduction even more than the silicate lattice $\mathrm{Fe}(\mathrm{III})$ because they are more directly exposed to the redox environment than the comparatively shielded structural iron. Chemical reduction of Fe(III) oxides and oxyhydroxides, however, implies iron mobilization and upward transport, as well as reoxidation and precipitation above the iron redox cline.

Therefore, reversible shifts of the $\mathrm{Fe}(\mathrm{II}) / \mathrm{Fe}(\mathrm{III})$ ratio within the silicate mineral content of sediments may be interpreted in terms of possible diagenetic dissolution and redistribution of iron oxide minerals in the seafloor. At Site 1062, this is important with respect to the lithostratigraphic value of the hematite-rich red lutites and their significance as advective proxies for deep circulation (Shipboard Scientific Party, 1998c).

Likewise, the oxidizable silicate Fe(II) content in a given sediment horizon may be interpreted as an indicator of possible chemical overprint on the primary magnetic signal in the seafloor, which principally resides in iron oxide minerals, especially magnetite. High magnetic susceptibility layers should be associated with little or no oxidizable silicate $\mathrm{Fe}$ (II) since they experienced iron oxide precipitation instead of dissolution. As a matter of fact, both a spike in the concentration of solid-phase iron (i.e., goethite) and enhanced sediment magnetic intensities (attributable to magnetic mineral authigenesis associated with early diagenesis) have been found in the near-surface sediments of the Blake/Bahama Outer Ridge sediments (Schwartz et al., 1997).

Also Torii (1997) observed manifest downcore changes in the magnetic properties (i.e., Verwey transition) across the iron redox boundary in deep-sea sediments (ODP Leg 161) from the western Mediterranean Sea. From his findings, he hypothesized in situ formation of a maghemite $\left(\gamma-\mathrm{Fe}_{2} \mathrm{O}_{3}\right)$ coating on primary magnetite grains above the redox boundary and dissolution of that coating, followed by progressive dissolution of the magnetite core itself, below the boundary. 


\section{KöNIG ET AL.

Thus, early diagenetic processes that affect the iron mineral assemblage in the sediment sequence are generally of interest with regard to the reliability of the magnetic record. This especially applies to the Leg 172 cores, which contain an extraordinarily detailed and complete record of the Earth's magnetic field variability for the past 1.2 m.y. (Shipboard Scientific Party, 1998c). The postdepositional shift of the $\mathrm{Fe}(\mathrm{II}) / \mathrm{Fe}(\mathrm{III})$ ratio within the silicate mineral content, as well as the other data on the sediment iron that are obtainable by Mössbauer spectroscopy, can in doubtful cases, together with rock magnetic methods, help to judge the authenticity of magnetic field excursion records. However, that information is getting lost during storage of the sediment cores.

\section{CONCLUSION}

Sediment qualities resulting from postdepositional iron diagenesis in the seafloor, such as reversible increases of the silicate lattice Fe(II)/ $\mathrm{Fe}(\mathrm{III})$ ratio, may undergo drastic changes even within the short time intervals of archive storage. Consequently, those qualities must be studied on fresh materials, subsampled immediately after core retrieval, and handled with the necessary care. It does not seem helpful to use archive materials for the respective scientific aims. However, the "primary" signal of the solid phase $\mathrm{Fe}(\mathrm{II}) / \mathrm{Fe}(\mathrm{III})$ record survives the archive storage because the diagenetic overprint to this pattern is essentially reversible (König et al., 1999). Therefore, even older cores retain information in the $\mathrm{Fe}(\mathrm{II}) / \mathrm{Fe}$ (III) record that may be of use with respect to, for example, correlations based on deposition cyclicity and astronomical age models (compare the variation in Figure F2B with the age given in Table T1).

As nearly the entire Fe(II) fraction in Site 1062 sediments is structural iron in silicates, iron oxidation during storage occurred within the silicate lattice structure, and the mineral assemblage remained unaltered. Consequently, modification of the magnetic signal during storage is unlikely in this case, whereas the reversible shift in the $\mathrm{Fe}(\mathrm{II}) / \mathrm{Fe}$ (III) ratio suggests that magnetic overprints might have occurred in the seafloor. Moreover, our findings imply that iron oxidation during storage, at least as intense as in the reported case, would probably occur in sediment cores containing significant amounts of authigenic Fe(II)-bearing carbonates or sulfides. With such other types of sediment core, Fe(III) oxides and oxyhydroxides would form, and a magnetic study parallel to Mössbauer investigations (of the changes that occur during archive storage) would be worthwhile to also observe and document alterations of the magnetic signal or properties.

\section{ACKNOWLEDGMENTS}

We thank the crew and scientific party of Leg 172 for collecting the sediment cores and the Ocean Drilling Program for providing the samples. The manuscript was much improved by constructive reviews from Eve Arnold, Carlo Laj, and Peter Solheid. We acknowledge financial support by the Deutsche Forschungsgemeinschaft (German Science Foundation, DU 129/15 1-2). 


\section{REFERENCES}

De Grave, E., and Van Alboom, A., 1991. Evaluation of ferrous and ferric Mössbauer fractions. Phys. Chem. Miner., 18:337-342.

Gütlich, P., Link, R., and Trautwein, A.X., 1978. Mössbauer Spectroscopy and Transition Metal Chemistry: Berlin (Springer-Verlag).

Karlin, R., Lyle, M., and Heath, G.R., 1987. Authigenic magnetite formation in suboxic marine sediments. Nature, 326:490-493.

König, I., Haeckel, M., Drodt, M., Suess, E., and Trautwein, A.X., 1999. Reactive Fe(II) layers in deep-sea sediments. Geochim. Cosmochim. Acta, 63:1517-1526.

König, I., and Hollatz, R., 1990. A fingerprint technique using Mössbauer spectroscopy for the determination of individual chemical iron species in young sediments. Hyperfine Interact., 57:2245-2250.

König, I., Knauth, H.-D., Koopmann, C., Wagner, F.E., and Wagner, U., 1988. Mössbauer studies of sediments and suspended matter from the river Elbe. Hyperfine Interact., 41:811-814.

Lancelot, Y., and Ewing, J.I., 1972. Correlation of natural gas zonation and carbonate diagenesis in Tertiary sediments from the north-west Atlantic. In Hollister, C.D., Ewing, J.I., et al., Init. Repts. DSDP, 11: Washington (U.S. Govt. Printing Office), 791-799.

Lyle, M., 1983. The brown-green color transition in marine sediments: a marker of the Fe(III)-Fe(II) redox boundary. Limnol. Oceanogr., 28:1026-1033.

Paull, C.K., Matsumoto, R., Wallace, P.J., et al., 1996. Proc. ODP, Init. Repts., 164: College Station, TX (Ocean Drilling Program).

Schwartz, M., Lund, S.P., Hammond, D.E., Schwartz, R., and Wong, K., 1997. Early sediment diagenesis on the Blake/Bahama Outer Ridge, North Atlantic Ocean, and its effects on sediment magnetism. J. Geophys. Res., 102:7903-7914.

Shipboard Scientific Party, 1998a. Deep Blake-Bahama Outer Ridge, Sites 1060, 1061, and 1062. In Keigwin, L.D., Rio, D., Acton, G.D., et al., Proc. ODP, Init. Repts., 172: College Station, TX (Ocean Drilling Program), 157-250.

—, 1998b. Introduction. In Keigwin, L.D., Rio, D., Acton, G.D., et al., Proc. ODP, Init. Repts., 172: College Station, TX (Ocean Drilling Program), 7-12.

- 1998c. Summary. In Keigwin, L.D., Rio, D., Acton, G.D., et al., Proc. ODP, Init. Repts., 172: College Station, TX (Ocean Drilling Program), 311-321.

Torii, M., 1997. Low-temperature oxidation and subsequent downcore dissolution of magnetite in deep-sea sediments, ODP Leg 161 (Western Mediterranean). J. Geomagn. Geoelect., 49:1233-1245. 


\section{KöNIG ET AL. \\ Iron OXIDATION IN SEDIMENT Cores (Site 1062)}

Figure F1. Mössbauer spectra (dots) and mathematical simulations (lines) of a Site 1062 sediment sample from 94 mbsf, which was subsampled on board ship immediately after core retrieval. The spectra were recorded at (A) $77 \mathrm{~K}$ and (B) $0.3 \mathrm{~K}$ without application of a magnetic field. Solid lines running across the data points represent the mathematical sum of the subspectra inside.

A

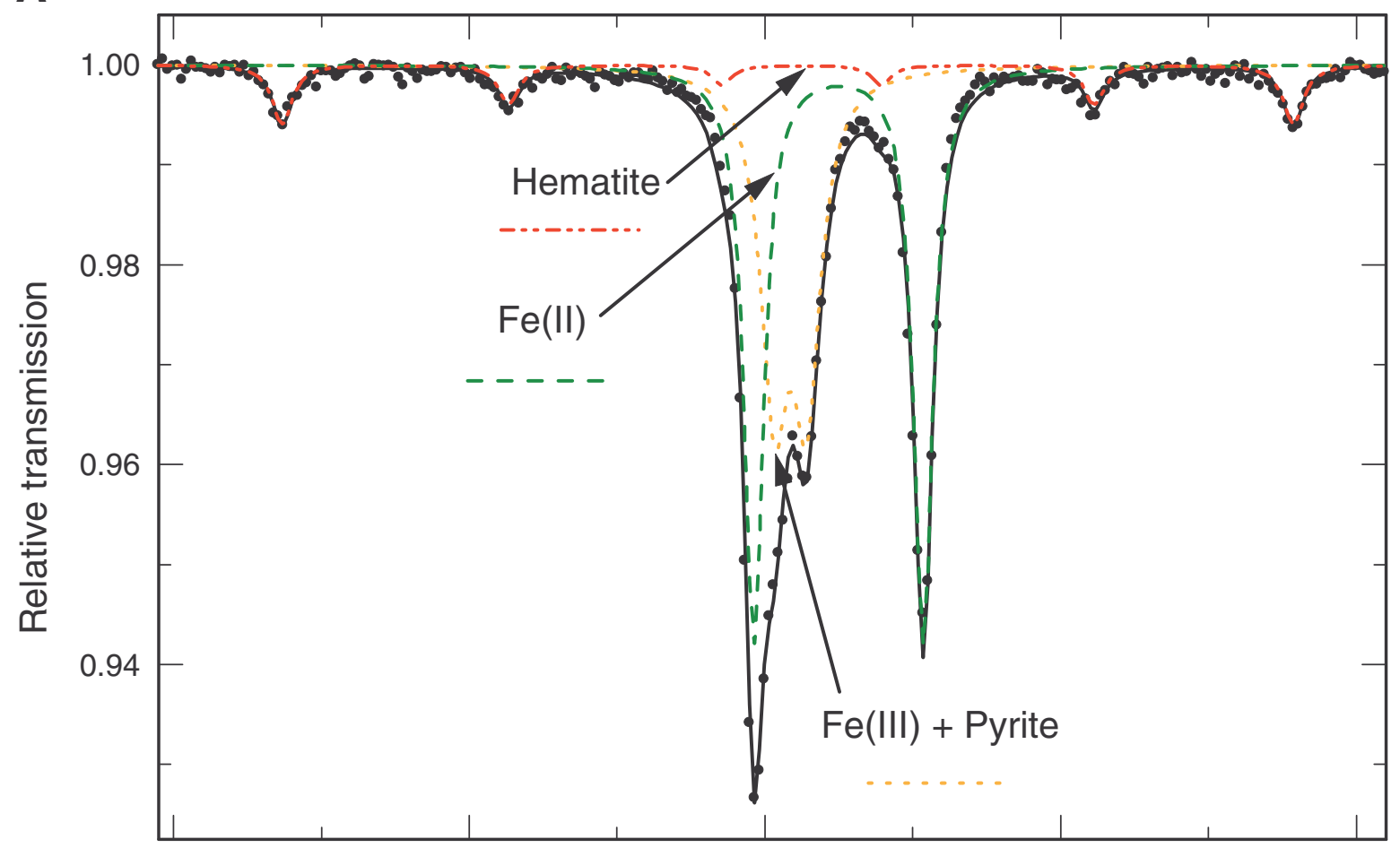

B

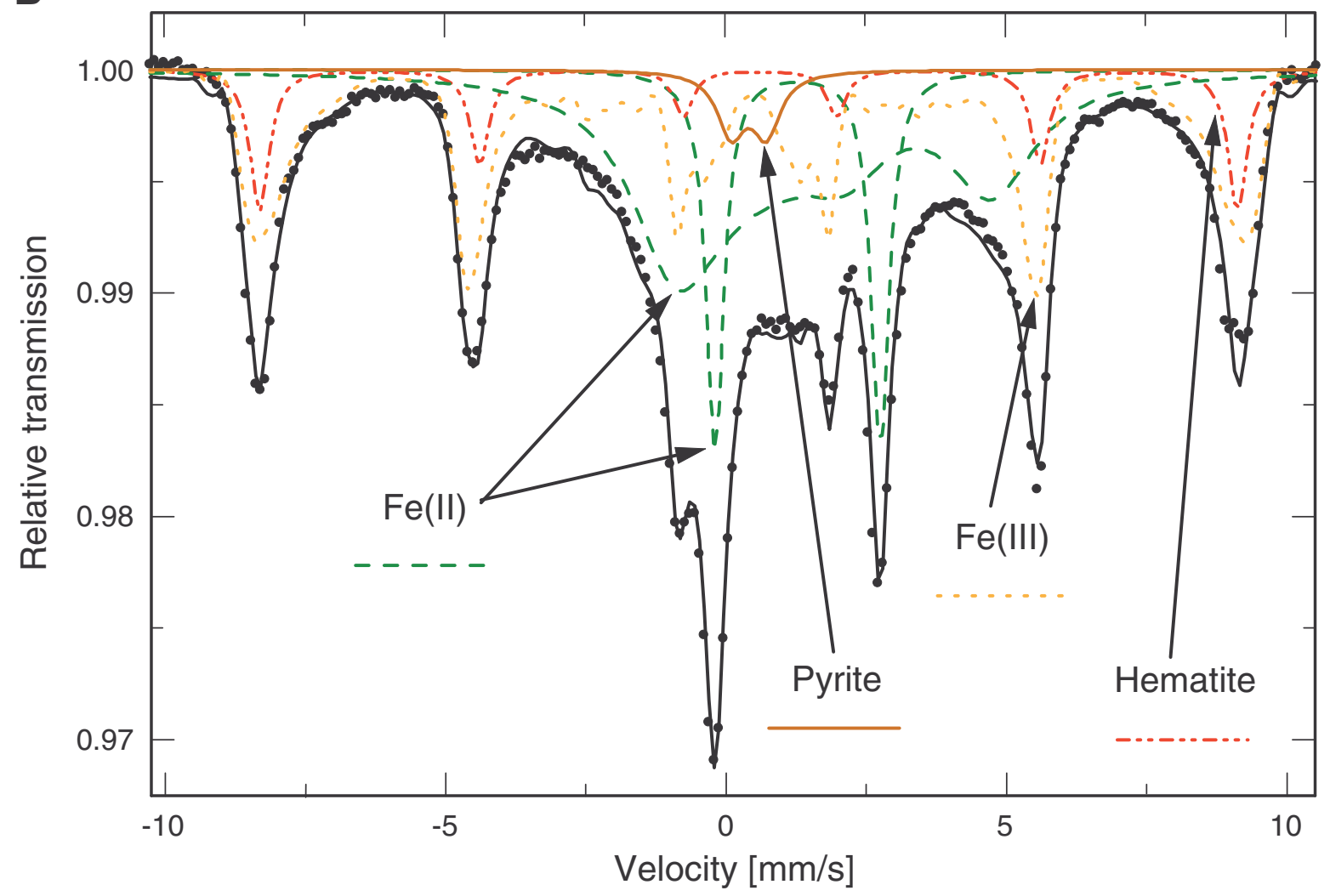


I. KöNIG ET AL.

Iron OXIDATION In SEDIMENT CoReS (Site 1062)

Figure F2. Fe(II) and Fe(III) fractions of the total iron content in 12 Site 1062 sediment samples obtained (A) immediately after core retrieval and (B) after 6 months of ODP archive storage.

A Sample number

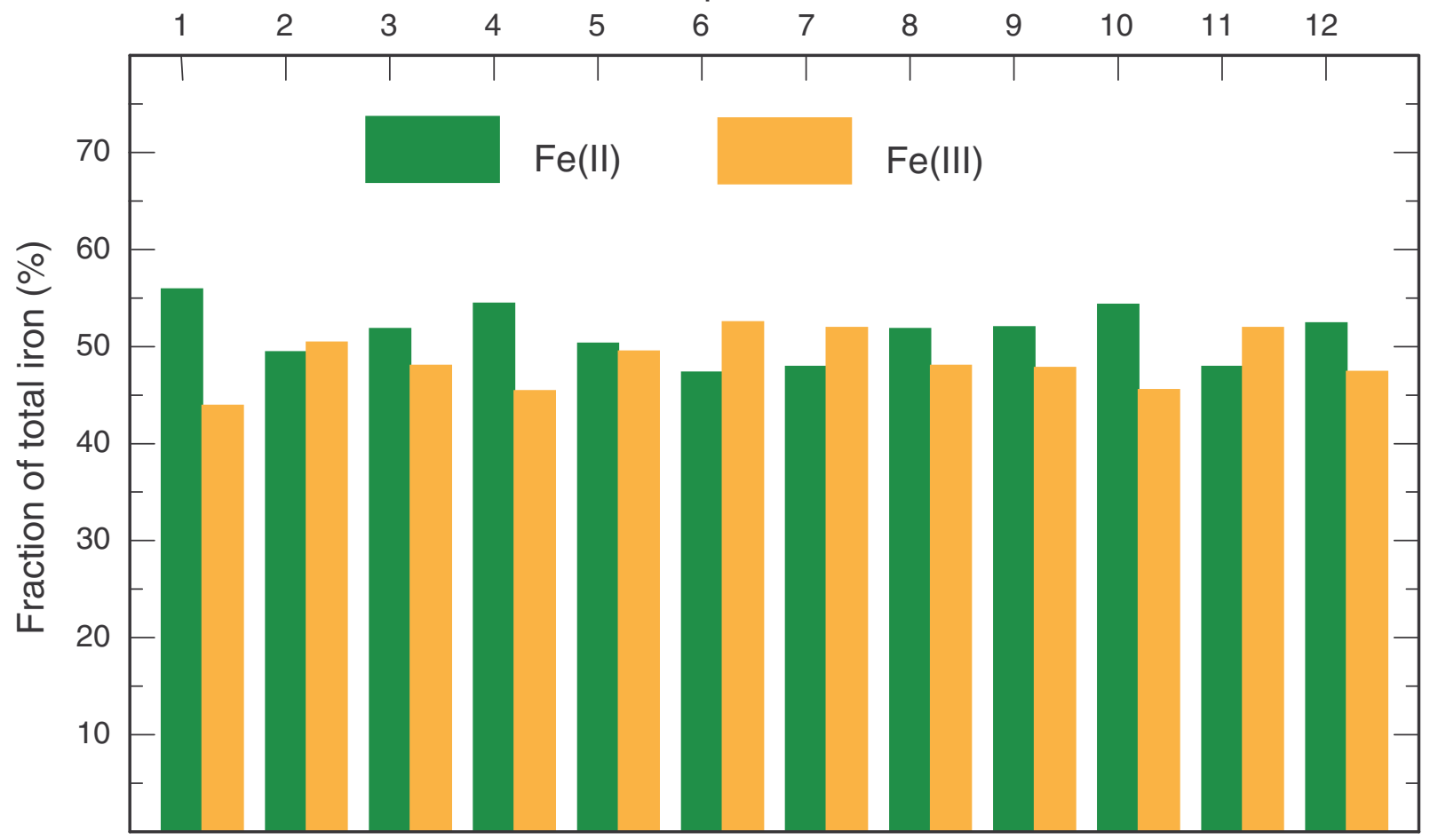

B

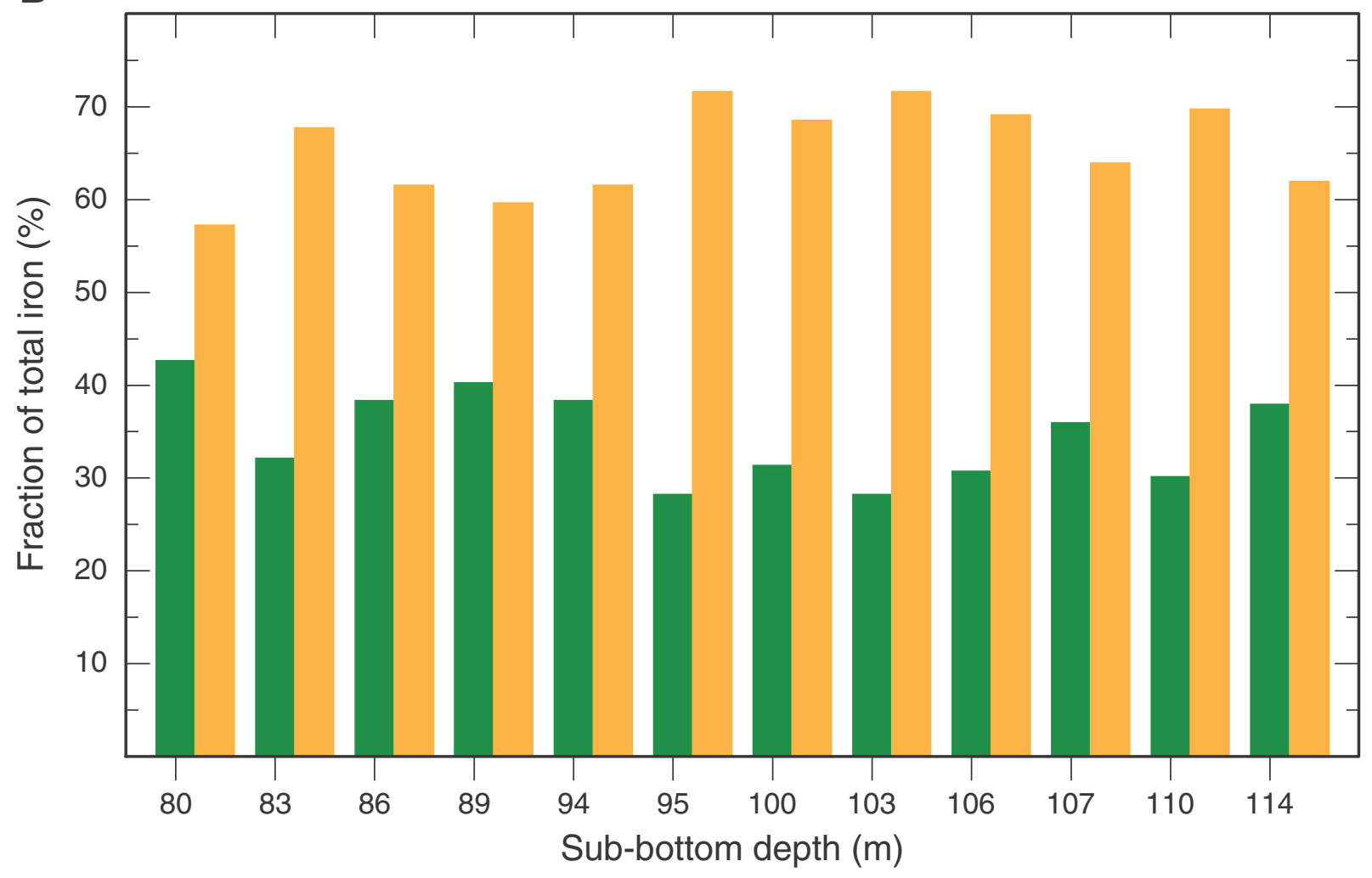




\section{KöNIG ET AL.}

Iron OXIDATION In SEDIMENT CoReS (Site 1062)

Table T1. Analyzed samples from Hole 1062A, including depth and age information.

\begin{tabular}{lrr}
\hline $\begin{array}{c}\text { Core, section, } \\
\text { interval }(\mathrm{cm})\end{array}$ & $\begin{array}{r}\text { Depth } \\
\text { (mbsf) }\end{array}$ & \multicolumn{1}{c}{$\begin{array}{c}\text { Age } \\
(\mathrm{ka})\end{array}$} \\
\hline $\begin{array}{l}\text { 172-1062A- } \\
10 \mathrm{H}-2,16-18\end{array}$ & 79.86 & 654.8 \\
$10 \mathrm{H}-4,46-48$ & 83.16 & 684.8 \\
$10 \mathrm{H}-6,46-48$ & 86.16 & 711.8 \\
$11 \mathrm{H}-2,10-12$ & 89.30 & 764.5 \\
$11 \mathrm{H}-5,10-12$ & 93.80 & 798.5 \\
$11 \mathrm{H}-6,10-12$ & 95.30 & 818.5 \\
$12 \mathrm{H}-2,125-127$ & 99.95 & 893.9 \\
$12 \mathrm{H}-4,125-127$ & 102.95 & 923.9 \\
$12 \mathrm{H}-6,125-127$ & 105.95 & 965.5 \\
$13 \mathrm{H}-1,50-52$ & 107.20 & 980.5 \\
$13 \mathrm{H}-3,60-62$ & 110.30 & 1017.0 \\
$13 \mathrm{H}-5,130-132$ & 114.00 & 1065.8 \\
\hline
\end{tabular}


I. KöNIG ET AL.

Iron OXIDATION In SEDIMENT CoReS (Site 1062)

Table T2. Distribution of total iron among Fe(II), $\mathrm{Fe}(\mathrm{III})_{\text {total minus hematite, }}$ and $\mathrm{Fe}(\mathrm{III})_{\text {in hematite. }}$

\begin{tabular}{cccc}
\hline $\begin{array}{c}\text { Depth } \\
(\mathrm{mbsf})\end{array}$ & $\begin{array}{c}\mathrm{Fe}(\mathrm{II}) \\
(\%)\end{array}$ & $\begin{array}{c}\mathrm{Fe}(\mathrm{III})_{\text {total minus hematite }} \\
(\%)\end{array}$ & $\begin{array}{r}\mathrm{Fe}(\mathrm{III})_{\text {in hematite }} \\
(\%)\end{array}$ \\
\hline \multicolumn{4}{l}{ Immediately after core retrieval: } \\
79.86 & 56.0 & 35.8 & \\
83.16 & 49.5 & 50.5 & 8.2 \\
86.16 & 51.9 & 37.9 & 0.0 \\
89.30 & 54.5 & 39.0 & 10.2 \\
93.80 & 50.4 & 39.0 & 6.5 \\
95.30 & 47.4 & 52.6 & 10.6 \\
99.95 & 48.0 & 41.1 & 0.0 \\
102.95 & 51.9 & 48.1 & 10.9 \\
105.95 & 52.1 & 47.9 & 0.0 \\
107.20 & 54.4 & 45.6 & 0.0 \\
110.30 & 48.0 & 44.8 & 0.0 \\
114.00 & 52.5 & 38.1 & 7.2 \\
After 6 months of ODP archive storage: & 9.4 \\
79.86 & 42.7 & 49.5 & \\
83.16 & 32.2 & 67.8 & 7.8 \\
86.16 & 38.4 & 51.3 & 0.0 \\
89.30 & 40.3 & 54.1 & 10.3 \\
93.80 & 38.4 & 51.3 & 5.6 \\
95.30 & 28.3 & 71.7 & 10.3 \\
99.95 & 31.4 & 58.4 & 0.0 \\
102.95 & 28.3 & 71.7 & 10.2 \\
105.95 & 30.8 & 69.2 & 0.0 \\
107.20 & 36.0 & 64.0 & 0.0 \\
110.30 & 30.2 & 62.8 & 0.0 \\
114.00 & 38.0 & 52.9 & 7.0 \\
& & 9.1 \\
\hline \multicolumn{5}{c}{} & &
\end{tabular}

